\title{
PSD-95 Alters Microtubule Dynamics via an Association With EB3
}

\author{
Eric S. Sweet, ${ }^{1,3}$ Michelle L. Previtera, ${ }^{1,2}$ Jose R. Fernández, ${ }^{1,2}$ Erik I. Charych, ${ }^{1}$ Chia-Yi Tseng, ${ }^{1,3}$ Munjin Kwon, ${ }^{1,2}$ \\ Valentin Starovoytov, ${ }^{1}$ James Q. Zheng, ${ }^{4}$ and Bonnie L. Firestein ${ }^{1}$ \\ ${ }^{1}$ Departments of Cell Biology and Neuroscience, ${ }^{2}$ Molecular Biosciences Graduate Program, and ${ }^{3}$ Graduate Program in Neuroscience, Rutgers University, \\ Piscataway, New Jersey 08854-8082, and ${ }^{4}$ Neuroscience and Cell Biology, University of Medicine and Denstistry of New Jersey, Piscataway, New Jersey \\ 08854-5635
}

Little is known about how the neuronal cytoskeleton is regulated when a dendrite decides whether to branch or not. Previously, we reported that postsynaptic density protein 95 (PSD-95) acts as a stop signal for dendrite branching. It is yet to be elucidated how PSD-95 affects the cytoskeleton and how this regulation relates to the dendritic arbor. Here, we show that the SH3 (src homology 3 ) domain of PSD-95 interacts with a proline-rich region within the microtubule end-binding protein EB3. Overexpression of PSD-95 or mutant EB3 results in a decreased lifetime of EB3 comets in dendrites. In line with these data, transfected rat neurons show that overexpression of PSD-95 results in less organized microtubules at dendritic branch points and decreased dendritogensis. The interaction between PSD-95 and EB3 elucidates a function for a novel region of EB3 and provides a new and important mechanism for the regulation of microtubules in determining dendritic morphology.

\section{Introduction}

Postsynaptic density protein-95 (PSD-95)/SAP-90 and family members assemble synaptic signaling complexes at excitatory synapses (Cho et al., 1992; Kistner et al., 1993; Brenman et al., 1996; Kim et al., 1998). These proteins have complex binding domains that allow them to perform many synaptic functions (Chen et al., 2000; El-Husseini et al., 2000; Chung et al., 2004; Steiner et al., 2008). We reported previously that PSD-95 exhibits a nonsynaptic function during hippocampal neuron development. Our previous findings suggest that PSD-95 inhibits proximal dendrite branching by disrupting microtubule organization (Charych et al., 2006).

Although much is known about how microtubules are regulated in the axon by motors and severing, stabilizing, and growthpromoting proteins (Fukata et al., 2002b; Qiang et al., 2006; Manna et al., 2007; Myers and Baas, 2007), less is known about the regulation of microtubule dynamics in determining dendritic arbor shape. Our work on cytosolic PSD-95 interactor (cypin)

\footnotetext{
Received March 8, 2010; revised Nov. 1, 2010; accepted Nov. 9, 2010.

This work was supported in part by a Busch Biomedical grant, National Science Foundation (NSF) Grants IBN0919747 and IBN-0548543, March of Dimes Foundation Grants 1-FY04-107 and 1-FY08-464, a grant-in-aid from the American Heart Association (B.L.F), and National Institutes of Health Grant R01 GM083889 (J.Q.Z.). E.S.S. was supported in part by National Institutes of Health Training Grants 5 T32 MH019957-10 and T32 GM00839. M.L.P. was supported by a University and Louis Bevier Graduate and Dissertation Fellowship. M.L.P. and J.R.F. were supported in part by the Integrative Graduate Education and Research Traineeship Program on Integratively Engineered Biointerfaces at Rutgers (NSF Grant DGE-0333196). E.I.C. was supported in part by a Pharmaceutical Manufacturers of America Foundation Postdoctoral Fellowship. We thank Dr. Anna Akhmanova for the generous gift of EB3 antibodies and shRNA, Christopher G. Langhammerfor writing the dendrite analysis program, and Dr. Chris Rongo for a critical reading of this manuscript.

*E.S.S. and M.L.P. contributed equally to this work.

Correspondence should be addressed to Dr. Bonnie L. Firestein at the above address. E-mail: firestein@biology.rutgers.edu.

J. Q. Zheng's present address: Department of Cell Biology, Emory University, Atlanta, GA 30322.

DOI:10.1523/JNEUROSCI.1205-10.2011

Copyright $\odot 2011$ the authors $\quad 0270-6474 / 11 / 311038-10 \$ 15.00 / 0$
}

strongly suggests that local regulation of microtubule polymerization influences dendrite arborization (Akum et al., 2004; Charych et al., 2006; Chen and Firestein, 2007). PSD-95 also associates with microtubule-associated proteins (MAPs), such as MAP1A, cysteinerich PDZ binding protein (CRIPT), adenomatous polyposis coli (APC), and cypin (Brenman et al., 1998; Passafaro et al., 1999; Yanai et al., 2000; Akum et al., 2004; Reese et al., 2007); however, it remains unclear as to how PSD-95 affects microtubules.

The plus ends of growing microtubules accumulate a diverse group of microtubule-associated proteins, collectively referred to as the plus-end-tracking proteins (+TIPs). + TIPs encompass a large number of unrelated proteins, which include motor and nonmotor proteins, regulatory proteins, and adaptor proteins. One + TIP binding protein family is the end-binding (EB) protein family. Like other + TIPs, EB proteins mediate interactions between the ends of microtubules, organelles, and protein complexes as well as altering microtubule stability (Lansbergen and Akhmanova, 2006; Akhmanova and Steinmetz, 2008; Honnappa et al., 2009; Komarova et al., 2009). Of three EB family members, EB3 is preferentially expressed in the CNS and is used to track microtubule dynamics (Nakagawa et al., 2000; Akhmanova and Hoogenraad, 2005; Komarova et al., 2005; Lansbergen and Akhmanova, 2006).

Here, we show that PSD-95 alters microtubule organization in neurons, resulting in decreased dendrite branching. PSD-95 performs this function via direct interaction with EB3 through the src homology 3 (SH3) domain on PSD-95. Deletion of the SH3 region (PSD-95 $\Delta \mathrm{SH} 3$ ) blocks the effects of PSD-95 on dendrite branching and microtubules. Overexpression of PSD-95 in cultured neurons results in decreased lifetime of EB3 comets in dendrites, suggesting decreased microtubule stability and alteration of microtubule organization and dendrite branching. Mutation 


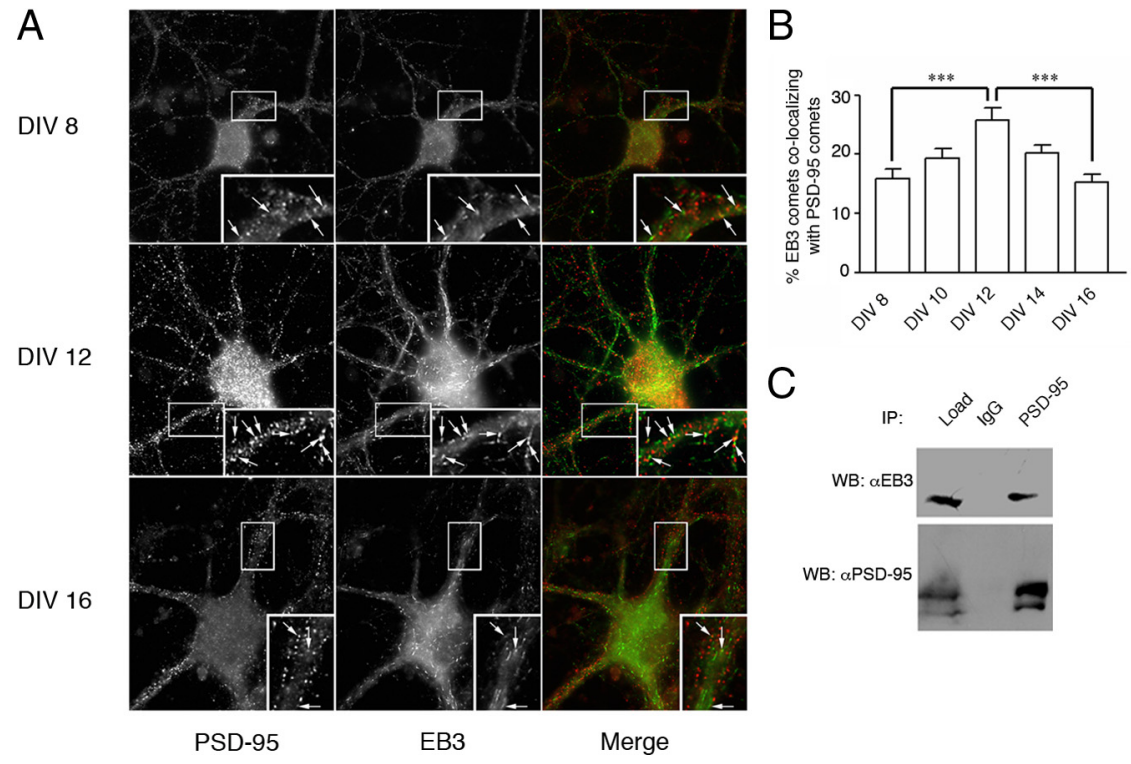

Figure 1. PSD-95 interacts with EB3. A, Colocalization of EB3 comets with PSD-95 puncta. Primary cultures of hippocampal neurons were fixed with ice-cold methanol followed by $4 \%$ paraformaldehyde. Double-label immunocytochemistry with antibodies to PSD-95 (left) and EB3 (middle) was performed. Images are overlaid for direct comparison (right). Inset, High magnification indicating colocalization of PSD-95 and EB3 puncta (arrows). B, Colocalization of EB3 and PSD-95 peaks at DIV12. Colocalization was quantified by calculating the proportion of total EB3 comets that overlay PSD-95 puncta. ${ }^{* * *} p<0.001$ by ANOVA followed by a Bonferroni multiple comparisons test. C, Coimmunoprecipitation of EB3 with PSD-95 from adult rat brain. EB3 coimmunoprecipitates with PSD-95. Detergent extracts from adult rat brain were subjected to immunoprecipitation with the indicated antibodies. IP, Immunoprecipitation; WB, Western blot.

of the polyproline region of EB3 eliminates binding of EB3 to PSD-95 and blocks the effect of PSD-95 on comet lifetime. Electron microscopic analysis of microtubules in neurons that overexpress PSD-95 confirms that PSD-95 alters microtubule organization, resulting in more microtubules crossing between the shafts at dendrite branch points. Based on these data, we present a novel mechanism by which PSD-95 can shape the dendritic arbor and cytoskeleton in developing hippocampal neurons via an interaction with EB3.

\section{Materials and Methods}

Antibodies. Mouse monoclonal antibodies recognizing PSD-95 (MA1-045, MA1-046) were purchased from Affinity BioReagents. Rabbit anti-PSD-95 was previously characterized (Firestein et al., 1999). Rabbit anti-EB3 was generously provided by Dr. Anna Akhmanova. Both monoclonal (MA1-046) and rabbit anti-PSD-95 are specific for PSD-95 (Firestein et al., 1999; Sans et al., 2000). Mouse anti-MAP2 and rabbit antiDsRed were purchased from BD-PharMingen. Rat anti-green fluorescent protein (GFP) was purchased from Santa Cruz Biotechnology.

Neuronal culture, immunocytochemistry, and transfection. Hippocampal cultures were prepared from rat embryos at $18 \mathrm{~d}$ gestation as described previously (Firestein et al., 1999; Akum et al., 2004; Chen et al., 2005). For transfection, the neurons were grown for 10 days in vitro (DIV) and transfected with the appropriate constructs using Effectene from Qiagen or by the calcium phosphate method (Xia et al., 1996). For immunocytochemical studies, neurons were fixed at DIV 12 or DIV 17 with icecold methanol for $15 \mathrm{~min}$ and immunostained with the following primary antibodies: mouse anti-PSD95 (1:200), rat anti-GFP (1:1000), rabbit antiEB3 (1:3000). Staining was visualized using secondary antibodies conjugated to Cy2 or Cy3 (Jackson ImmunoResearch Laboratories).

Coimmunoprecipitation from brain detergent extracts. Rat forebrain (1 g wet weight) was homogenized in $5 \mathrm{ml} \mathrm{TEE} \mathrm{(20} \mathrm{mM} \mathrm{Tris-} \mathrm{HCl}, \mathrm{pH} 7.4,1$ mM EDTA, 1 mM EGTA, pH 7.4) and incubated with an equal volume of $2 \times$ RIPA buffer (100 mm Tris-HCl, pH 7.4, $300 \mathrm{~mm} \mathrm{NaCl}, 1 \%$ deoxycholate, $2 \%$ NP-40, $0.2 \%$ SDS, 2 mm EDTA, pH 7.4) containing $1 \mathrm{~mm}$ phenylmethylsulfonylfluoride (PMSF) and protease inhibitor cocktail
(Roche) at $4^{\circ} \mathrm{C}$ for $1 \mathrm{~h}$. Detergent-insoluble material was pelleted by centrifugation at $15,000 \times g$ for $10-15 \mathrm{~min}$ at $4^{\circ} \mathrm{C}$. Antibody $(10$ $\mu \mathrm{l})$ was added to the extract and incubated overnight at $4^{\circ} \mathrm{C}$, followed by the addition of 25-50 $\mu$ l protein A Sepharose (GE Healthcare). After a $1-2 \mathrm{~h}$ incubation at $4^{\circ} \mathrm{C}$, washed beads were incubated with SDS-PAGE sample buffer $(0.01$ м Tris-HCl, $\mathrm{pH} 6.8,20 \%$ glycerol, $10 \% \beta$-mercaptoethanol, $2.3 \%$ SDS, $0.005 \%$ bromophenol blue) for $20 \mathrm{~min}$ at room temperature (RT) followed by centrifugation. The supernatant was boiled and subjected to SDS-PAGE and Western blotting using the indicated antibodies.

COS-7 cell culture, transfection, and coimmunoprecipitation. COS-7 cells were plated at 70$80 \%$ confluence and maintained in DMEM (Invitrogen), supplemented with $7.5 \%$ fetal bovine serum in a $5 \% \mathrm{CO}_{2}$ atmosphere. Cells were transfected with $1.5 \mu \mathrm{g}$ of the indicated plasmid DNA encoding the indicated proteins using LipofectAMINE 2000 (Invitrogen) following the manufacturer's instructions. COS-7 cells were transfected with cDNAs encoding wild-type EB3 tagged with monomeric red fluorescent protein (mRFP) and either wild-type PSD-95-GFP, PSD-95 $\Delta$ SH3-GFP, or GFP using Lipofectamine 2000 (Invitrogen), as per the manufacturer's protocol. Cells were lysed in TEE and solubilized using Triton X-100 at a final concentration of $1 \%$. Insoluble material was pelleted at $15000 \times g$, and lysate was incubated with anti-PSD-95 antibody overnight at $4^{\circ} \mathrm{C}$ and then with protein A Sepharose for $1 \mathrm{~h}$. Beads were isolated and bound proteins were eluted in SDS-PAGE sample buffer. Samples were boiled and subjected to SDSPAGE and Western blotting using the indicated antibodies.

Microtubule immunoprecipitation. Immunoprecipitation of microtubules was performed as described previously (Wersinger and Sidhu, 2005). Briefly, COS-7 cells were incubated and proteins were extracted for $15 \mathrm{~min}$ at RT with $0.5 \% \mathrm{NP}-40$ in a microtubule stabilization buffer [20 mм Tris, pH 6.9, 0.5\% (v/v) NP-40, 2 м glycerol, 10\% (v/v) DMSO, 1 mм MgCl2, 2 mм EGTA, 200 m sodium orthovanadate, 1 mм PMSF, and the aforementioned protease inhibitor cocktail]. Detergent-insoluble material was pelleted by centrifugation at $15,000 \times g$, and soluble extracts were used for immunoprecipitation with a mouse anti-acetylated tubulin antibody. Immunoprecipitation procedure was done as described above except that all steps were performed at room temperature.

Microtubule polymerization assay. Tubulin $(30 \mathrm{M})$ was mixed with purified glutathione $S$-transferase (GST) fusion proteins $(4 \mathrm{M})$ in PEM (0.1 м PIPES, 5 mм EDTA, 5 mm $\mathrm{MgCl}_{2}$ ) buffer containing $10 \%$ glycerol and $1 \mathrm{~mm}$ GTP on ice. The mixture was then incubated at $37^{\circ} \mathrm{C}$, and tubulin polymerization was detected by measuring the absorbance at 355 $\mathrm{nm}$ once per minute for $1 \mathrm{~h}$.

Filter overlay assay. Bacterial expression and purification of GST fusion proteins were performed as reported previously (Fernando et al., 1995; Charych et al., 2006). For the overlay assay, lysates from COS-7 cells expressing EB3-GFP were subjected to SDS-PAGE and transferred to polyvinylidene difluoride (PVDF) membrane. Membrane strips containing immobilized EB3-GFP were washed three times with TBST (10 mm Tris$\mathrm{HCl}, \mathrm{pH} 7.5,200 \mathrm{~mm} \mathrm{NaCl}, 0.2 \%$ Tween-20) for $5 \mathrm{~min}$ each and blocked with TBST containing 5\% nonfat dried milk (NFDM) for $2 \mathrm{~h}$. Strips were incubated with $0.25 \mu \mathrm{M}$ of the indicated GST fusion protein for $15 \mathrm{~h}$, followed by three washes with TBST for 5 min each. All of the above steps were done at RT. The strips were incubated with TBST containing 5\% NFDM for $30 \mathrm{~min}$ at RT followed by incubation with anti-GST antibody (Millipore Biotechnologies,) diluted 1:2000 in TBST with agitation at $4^{\circ} \mathrm{C}$ overnight.

Molecular modeling. The active structures of the PSD-95 fragment containing the $\mathrm{SH} 3$, guanylate kinase $(\mathrm{GK})$, and HOOK region between 
A

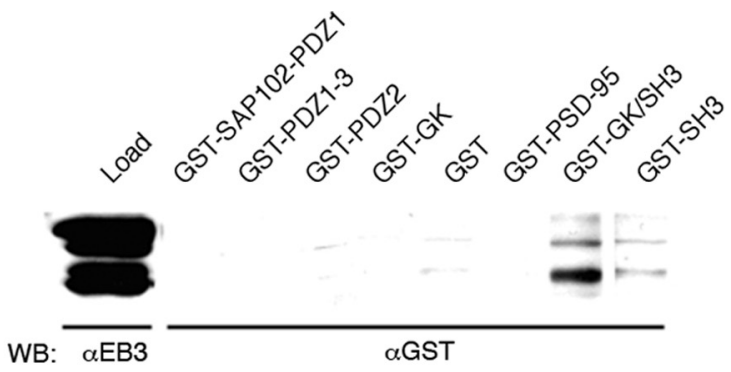

C

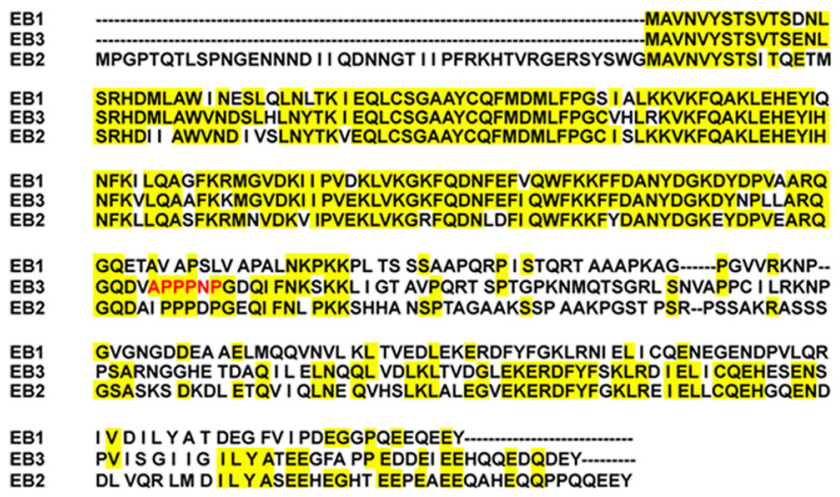

B

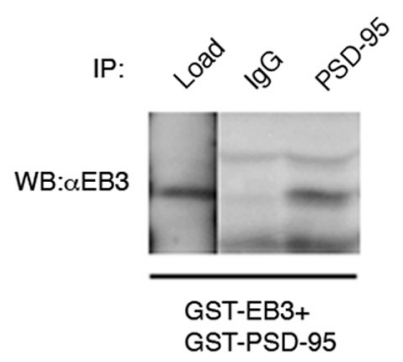

$\mathrm{D}$

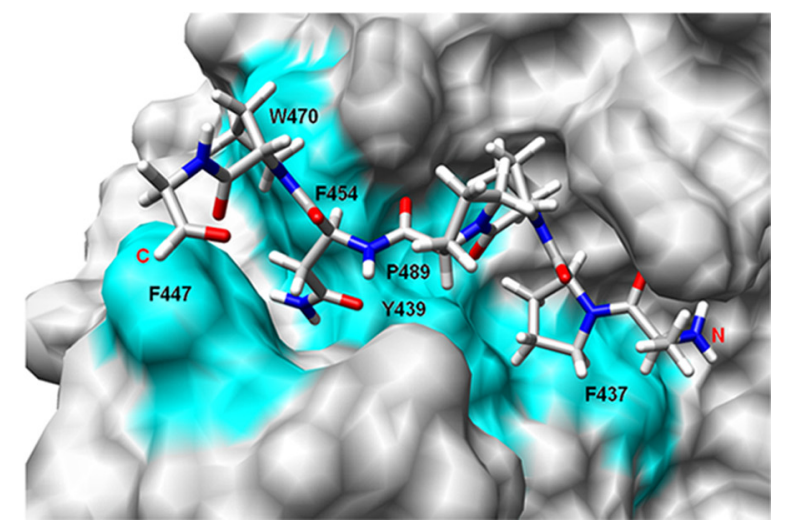

Figure 2. The SH3 domain of PSD-95 directly binds to a polyproline-rich region of EB3.A, EB3 directly interacts with the SH3 domain of PSD-95. Lysates from COS-7 cells expressing EB3-GFP were resolved by SDS-PAGE and transferred to PVDF membrane. Membrane strips were overlayed with the indicated GST fusion proteins of PSD-95 domains followed by immunoblotting with an antibody to GST. B, Purified EB3 and PSD-95 interact directly. Equimolar amounts of purified, bacterially expressed GST-EB3 and GST-PSD-95 were incubated at $4^{\circ} \mathrm{C}$ overnight followed by immunoprecipitation with an antibody to PSD-95. Precipitates were subjected to immunoblotting with an antibody to EB3. IP, Immunoprecipitation; WB, Western blot. C, Sequence alignment of the EB microtubuleassociated protein family members. EB3 contains a polyproline region. Conserved residues are highlighted in yellow and boxed. The gaps are indicated with dashes. An EB3-specific proline-rich residue motif is highlighted in red from amino acids 136 to 141. D, Display of the best EB3 proline-rich peptide conformation and its accommodation in the SH3-binding groove of PSD-95 after docking using GOLD. The peptide was rendered in element-coded sticks (red, oxygen; blue, nitrogen; white, hydrogen; gray, carbon) and the N and C termini are indicated. The PSD-95 structure is shown using a gray-coded solvent accessible surface (SAS), and residues in the SH3 domain in PSD-95 involved in the peptide binding are shown in cyan.

the SH3 and GK domains [Protein Data Bank (PDB) ID, 1JXO] (Tavares et al., 2001) and the solution structure of EB3 containing the calponin homology domain (PDB ID, 1WYO) were chosen as the models for the protein binding simulation. The structures were retrieved from the Research Collaboratory for Structural Bioinformatics Protein Data Bank (http://www.rcsb.org/pdb) (Berman et al., 2007). All of the molecular depictions were studied and visually analyzed using the UCSF Chimera package from the Resource for Biocomputing, Visualization, and Informatics at the University of California, San Francisco (Pettersen et al., 2004).

Molecular docking. Chain A of the PSD-95 structure (PDB ID, 1JXO) and a heptapeptide from the EB3 structure (APPPNPG) (PDB ID, 1WYO) were extracted and manually modified using Sybyl, version 7.2. Before ligand docking, the PSD-95 structure was energy minimized using the Tripos Force Field (Clark et al., 1989) and Powell method using 1000 iterations after addition of $\mathrm{H}$-bond hydrogens to the structures. In addition, the heptapeptide from the EB3 structure was energy minimized with the Tripos force field and a conjugated gradient method with 1000 iterations per procedure after addition of hydrogens and GasteigerHückel charge assignation (Gasteiger and Marsili, 1980). The Genetic Optimization of Ligand Docking (GOLD) docking program (Jones et al., 1997) was used to dock the heptapeptide into the proline-rich peptide binding groove in the SH3 domain of PSD-95 as described previously (Tavares et al., 2001). The default algorithm speed was selected during GOLD docking, and the number of poses for each inhibitor was set to 10 . The peptide binding site was defined as SH3-PSD-95 residues within a 30 $\AA$ radius of the center of Trp470. The best conformation solution result was used to analyze the protein-peptide binding interface.

$X$-gal staining and electron microscopy. Hippocampal cultures were grown (Masahira et al., 2005) for $10 \mathrm{~d}$ in culture on Thermanox coverslips (Electron Microscopy Sciences). The neurons were cotransfected with cDNA encoding $\beta$-galactosidase and GFP or PSD-95-GFP using the calcium phosphate transfection method. Neurons were fixed at DIV 12 with $2.5 \%$ glutaraldehyde in $0.1 \mathrm{~m}$ cacodylate buffer, $\mathrm{pH} 7.3$, at room temperature for $10 \mathrm{~min}$, and washed at room temperature in wash buffer $\left(0.1 \mathrm{M}\right.$ Tris, $\left.\mathrm{pH} 7.3,2 \mathrm{~mm} \mathrm{MgCl}_{2}\right)$ and staining buffer $(5 \mathrm{~mm}$ $\mathrm{K}_{4}\left[\mathrm{Fe}(\mathrm{CN})_{6}\right] \cdot 3 \mathrm{H}_{2} \mathrm{O}, 5 \mathrm{~mm} \mathrm{~K}_{3}\left[\mathrm{Fe}(\mathrm{CN})_{6}\right], 2 \mathrm{~mm} \mathrm{MgCl}_{2}, 20$ mм Tris, $\mathrm{pH}$ $7.3,0.1 \%$ Triton $\mathrm{X}-100)$. Staining for $\beta$-galactosidase was performed overnight at $37^{\circ} \mathrm{C}$ with $1 \mathrm{mg} / \mathrm{ml} \mathrm{X}$-gal (Omega Bio-Tek). The cultures were postfixed in $1 \% \mathrm{OsO}_{4}$ in wash buffer for $1 \mathrm{~h}$. Postfixed cultures were rinsed with water, dehydrated in ethanol, and embedded using the EMbed 812 kit (Electron Microscopy Sciences). The embedded cultures were cut parallel to the culture surface and imaged with a JEOL 100 CX transmission electron microscope (Division of Life Sciences, Rutgers University Electron Imaging Facility). Microtubule crossings at branch points were counted in along a linear axis that was $0.5 \mu \mathrm{M}$ long, beginning at the branch point and extending into the neuron perpendicular from membrane edge using Image $(\mathrm{NIH})$. An example of this analysis is shown in Figure 5E.

Time-lapse video microscopy of EB3-GFP comets in hippocampal neurons. Hippocampal cultures were prepared as described above and plated at a density of 250 cells $/ \mathrm{mm}^{2}$ on glass-bottom $35 \mathrm{~mm}$ culture dishes (WPI). Neurons were transfected with the appropriate constructs at plating using the Amaxa electroporation (Lonza Biologics). Time-lapse fluorescence imaging was performed $12-18 \mathrm{~h}$ after transfection. For live-cell imaging, culture medium was replaced with Ringer's solution [(in mM) $150 \mathrm{NaCl}, 5 \mathrm{KCl}, 2 \mathrm{CaCl} 2,1 \mathrm{MgCl}_{2}, 10$ glucose, 10 HEPES, pH 7.4] 18-24 $\mathrm{h}$ after transfection, and images were acquired on a Olympus Optical IX50 microscope equipped with a $60 \times$ oil-immersion objective, heated stage, Cooke Sensicam CCD cooled camera, fluorescence imaging system, and ImagePro software (MediaCybernetics). Images were taken 1 per second for $100 \mathrm{~s}$. Movies were adjusted for brightness, contrast, and gamma correction and then cropped to created time-lapse representa- 
A

GFP
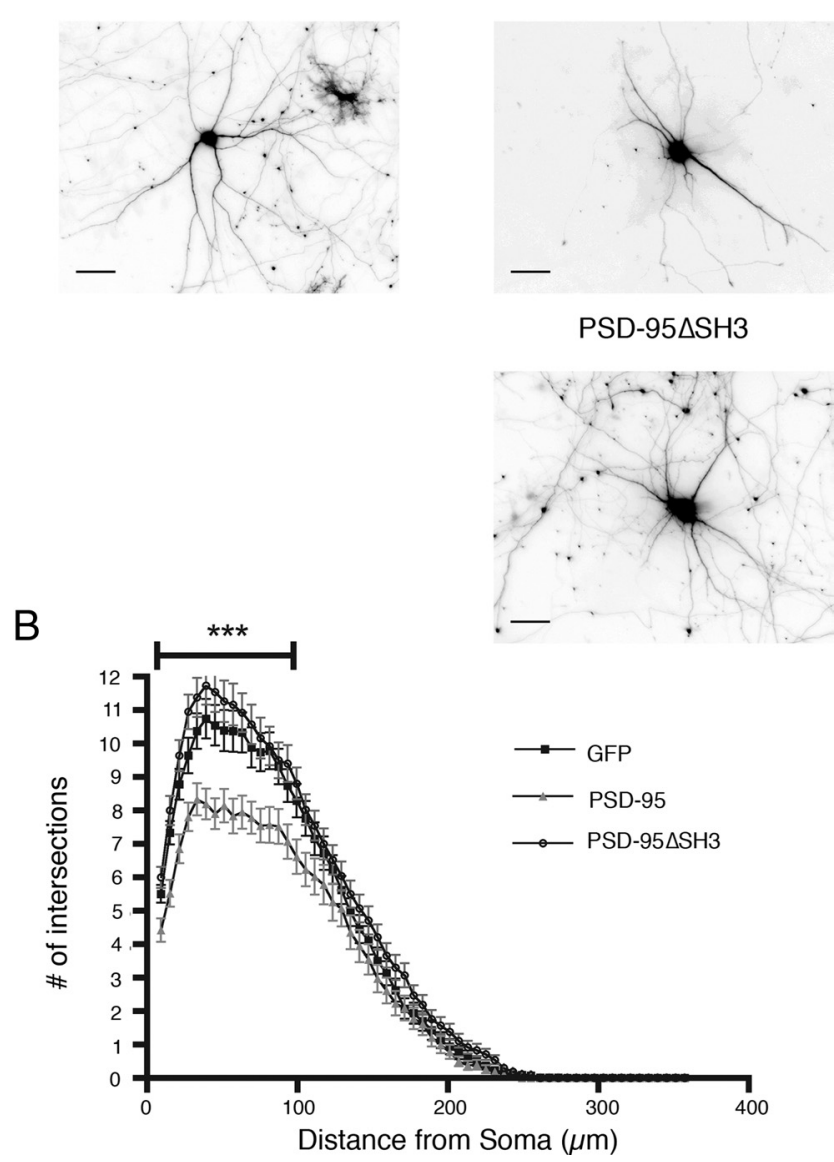

Figure 3. Deletion of the SH3 binding region in PSD-95 rescues PSD-95-induced branching deficits. $\boldsymbol{A}$, Representative inverted GFP images of hippocampal neurons transfected with the CDNA constructs for the indicated proteins. Neurons were transfected on DIV 7 and analyzed for dendrite number at DIV 12. Scale bars: $50 \mu \mathrm{m}$. B, Sholl analysis of neurons transfected with cDNA constructs encoding PSD-95-GFP, PSD-95 $\triangle$ SH3-GFP, or GFP. Neurons expressing PSD-95 $\triangle$ SH3-GFP do not show PSD-95-promoted decreases in dendritic arborization but instead show similar levels of branching to neurons expressing GFP up to a distance of $100 \mu \mathrm{m}$ from the cell body. ${ }^{* *} p<0.001$ by ANOVA followed by Bonferroni multiple comparisons test. $n=42$ neurons for each condition. Error bars indicate SEM.

tions. Comet velocity and lifetime were analyzed using Image (NIH). Comet movement was measured from the tip of each comet. Velocity was quantified as length traveled (micrometers) versus time (seconds). Comet lifetime was quantified by measuring the length of time that comets are visible in the dendrite. Images were prepared for presentation with Adobe Photoshop to adjust cropping, levels, and contrast, and all images were subjected to the same adjustments.

Dendrite analysis and imaging. Neurons were imaged in the GFP channel at $200 \times$ using an Olympus Optical IX50 microscope with a Cooke Sensicam CCD cooled camera, fluorescence imaging system, and ImagePro software (MediaCybernetics). Dendrite morphology was digitized in three stages based on these initial images. In the first stage, the semiautomated tools available through the NeuronJ plug-in to ImageJ $(\mathrm{NIH})$ were used to define coordinates of all dendrites in the $x-y$ plane. In the second stage, NeuronStudio was used to define the pattern of connectivity between dendrites. These two steps fully determine the structure of each cell's dendritic arbor and encode it in a digital format. Custom scripts written in MATLAB (MathWorks) were used to transfer the data from NeuronJ to NeuronStudio. Using these digitized dendritic arbors, a second set of MATLAB scripts were then used to analyze data and perform Sholl analysis with a $9.3 \mu \mathrm{m}$ ring interval. The data were transferred to Excel to facilitate statistical analysis. The experimenter was
A

IP: aAcetylated tubulin

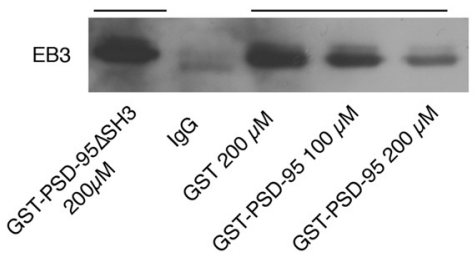

B
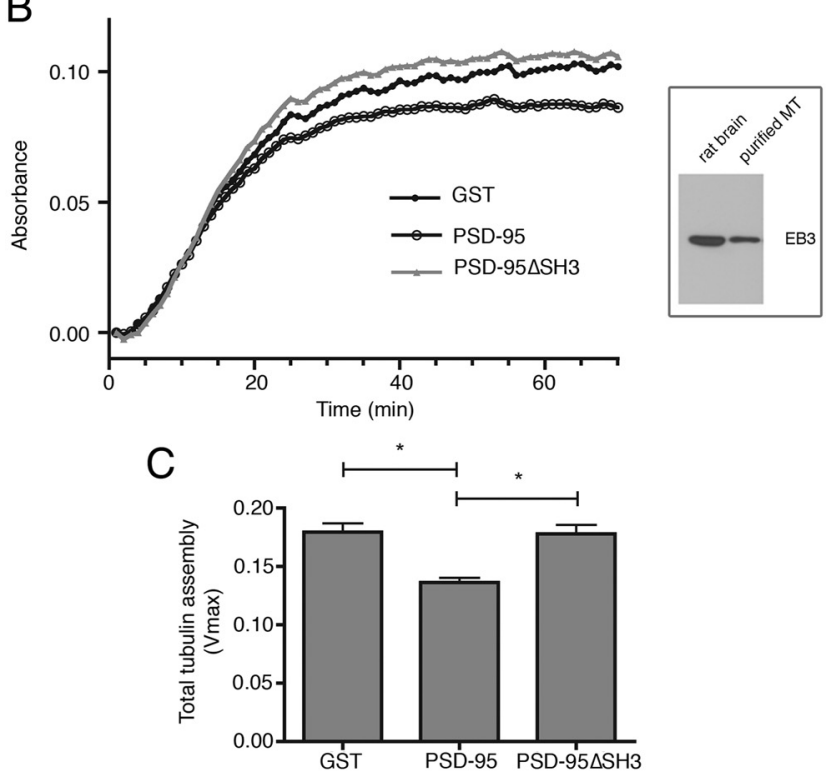

Figure 4. PSD-95 decreases the binding of EB3 to microtubules in heterologous cells and inhibits microtubule assembly in a cell-free system. $A$, Microtubules were immunoprecipitated from lysates of COS-7 cells expressing EB3-GFP and exogenously added GST-PSD-95 or GST-PSD$95 \Delta$ SH3. Immunoprecipitates were subjected to SDS-PAGE and Western blotting for the presence of EB3. $\boldsymbol{B}$, Light scattering of microtubules at $\mathrm{OD}_{355}$ in the presence of $1 \mathrm{~mm}$ GTP was used to detect the effect of PSD-95 on microtubule polymerization. Addition of $4 \mathrm{~m}$ GST-PSD-95, but not GST-PSD-95 $\Delta$ SH3, slows the polymerization of purified tubulin compared to the addition of equimolar concentrations of GST alone. Inset, Western blots of purified tubulin fractions (right lane), used in the above polymerization assay, show detectable amounts of EB3. The immunoreactive protein band comigrates with that from a rat brain homogenate (left lane). C, Quantification of total tubulin polymerization shows that GST-PSD-95, but not GST-PSD-95 $\triangle$ SH3, lowers the total amount of polymerization that occurred as measured by $V_{\max }$ of the curve. ${ }^{*} p<0.05$ by two-way repeated measures ANOVA followed by a Bonferroni multiple comparisons test to compare each point on the curve. $n=3$. Error bars indicate SEM.

blinded to conditions during all data analysis. Dendrites $<3 \mu \mathrm{m}$ in length were not counted (Yu and Malenka, 2004; Charych et al., 2006).

\section{Results}

EB3 is in a protein complex with PSD-95

We showed previously that PSD-95 regulates dendrite branching in cultured hippocampal neurons and alters microtubule organization in COS-7 cells (Charych et al., 2006). Because PSD-95 family members have been shown to indirectly bind to microtubules (Brenman et al., 1998; Passafaro et al., 1999), we hypothesized that PSD-95 may regulate dendritic arborization by interacting with the cytoskeleton. To test this hypothesis, we characterized the time course of colocalization of PSD-95 and EB3, a neuronal form of the plus-tip binding proteins that is associated with growing microtubules (Nakagawa et al., 2000; Stepanova et al., 2003) in cultured hippocampal neurons (Fig. $1 A, B)$. We found that the percentage of colocalization was highest at DIV 12 (Fig. $1 \mathrm{~B}$ ), which is the peak of dendrite branching (Dotti et al., 1988; Akum et al., 2004). We then hypothesized that 
A

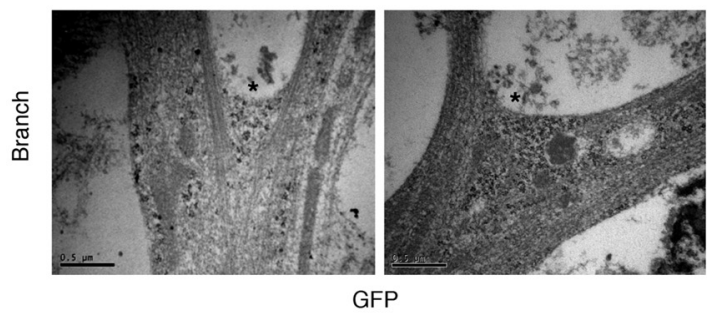

B

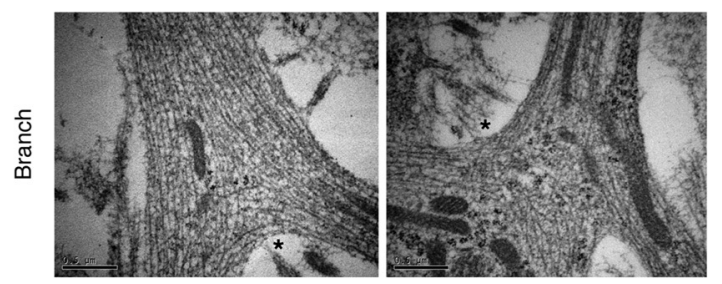

C

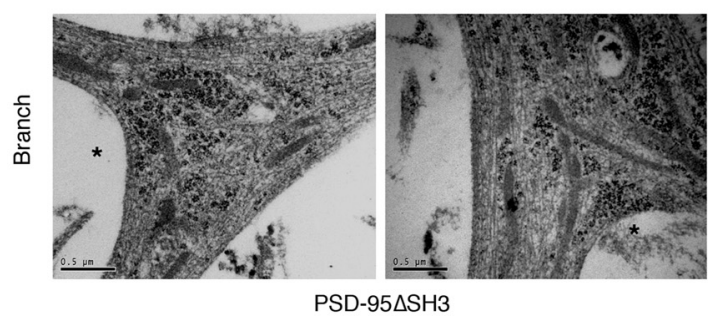

D

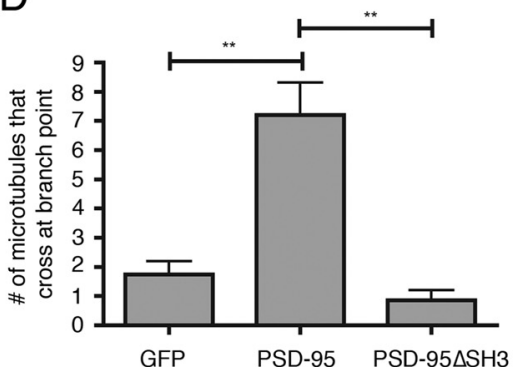

E

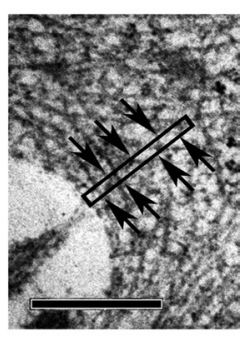

Figure 5. PSD-95 increases microtubule crossing at dendrite branch points. A-C, EM images of microtubules of hippocampal neurons transfected at DIV 10 and fixed on DIV 12. Asterisks indicate a branch point from a dendrite. $\boldsymbol{A}$, Control neurons that express GFP have organized microtubules at dendrite branch points. $\boldsymbol{B}$, Neurons that overexpress PSD-95-GFP show disorganized microtubules at that cross at dendrite branch points when compared to control GFP expressing neurons. C, Neurons that express PSD-95 $\triangle$ SH3-GFP show organized microtubules at dendrite branch points, similar to control neurons expressing GFP. D, Quantitation of the number of microtubules that cross at dendrite branch points in transfected hippocampal neurons represented in $\boldsymbol{A}-\boldsymbol{C}$. Microtubules cross dendrite branch points more often in neurons that overexpress PSD-95-GFP when compared to microtubules of neurons that overexpress GFP or PSD-95 SH3 GFP. ${ }^{* *} p<0.01$ by Kruskal-Wallis test followed by Dunn's multiple comparison test. $n=5$ neurons for each condition. $\boldsymbol{E}$, Example of how microtubule crossings were counted. A $0.5 \mu \mathrm{m}$ line (black box) was drawn and any microtubules crossing that line were counted (arrows). Scale bars: A-C, E, $0.5 \mu \mathrm{m}$. Error bars indicate SEM.

PSD-95 and EB3 may reside in a protein complex, and to test whether such an interaction exists, we performed coimmunoprecipitation experiments using rat brain extracts. We found that EB3 binds to PSD-95 (Fig. 1C) but not to SAP-102 or SAP-97 (data not shown). These data indicate that the interaction between EB3 and PSD-95 is specific.

EB3 interacts with PSD-95 via a direct interaction between a polyproline region in EB3 and the SH3 domain of PSD-95

We then asked whether the interaction between PSD-95 and EB3 is direct. Overlay assays indicated that filter-bound EB3-GFP binds to an overlaid portion of the PSD-95 polypeptide that con- tains the $\mathrm{SH} 3$ domain as well as one containing both the $\mathrm{SH} 3$ and guanylate kinase domains but not to those portions of PSD-95 containing PDZ (PSD-95/Discs large/zona occludens-1) domains $1-3$ or the guanylate kinase domain alone (Fig. 2 A). Interestingly, EB3-GFP did not interact with the full-length PSD-95 in this assay, suggesting that this interaction cannot occur when the full-length PSD-95 is not properly folded. To test this possibility, we coincubated equimolar amounts of purified GST-EB3 and GST-PSD95 followed by immunoprecipitation with an antibody to PSD-95 or with mouse IgG. As shown in Figure $2 B$, an antibody to PSD-95 but not mouse IgG coimmunoprecipitated EB3 in this assay, suggesting that both full-length PSD-95 and EB3 must assume specific three-dimensional structures to bind. Notably, the SH3 and GK domains of PSD-95 can bind intramolecularly and intermolecularly, altering the availability of the $\mathrm{SH} 3$ domain for EB3 binding (McGee and Bredt, 1999; McGee et al., 2001).

We then performed sequence analysis of the EB proteins to identify a potential binding site in EB3 for the $\mathrm{SH} 3$ domain of PSD-95. This analysis and in silico molecular docking analysis indicated that the $\mathrm{SH} 3$ domain of PSD-95 interacts with a proline-rich hexapeptide (APPPNP), corresponding to amino acids $136-141$ on the EB3 polypeptide (Fig. $2 C, D$ ). These results suggest that the SH3 domain of PSD-95 interacts directly with $\mathrm{EB} 3$, possibly via a proline-rich region in EB3.

Although EB2 contains a similar proline-region, we did not use it as a focus of our studies because EB3 is preferentially expressed in the CNS (Nakagawa et al., 2000). EB2 is also not as significant a contributor to suppression of microtubule catastrophe (Komarova et al., 2009) and does not form dimers with either EB1 or EB3 (De Groot et al., 2009). EB2 does not localize to the plus end of the microtubule in distinct comets (Jaworski et al., 2009). Thus, our studies focused on the interaction between PSD-95 and EB3.

\section{The interaction between PSD-95 and EB3 regulates the dendritic arbor}

PSD-95 stops dendrite branching (Charych et al., 2006), and the interaction between PSD-95 and EB3 may play a role in this process, perhaps by sequestering EB3, thereby inhibiting microtubule growth and organization. To test this hypothesis, we asked whether direct binding of PSD-95 to EB3 is essential for proper dendritogenesis. We created a mutant of PSD-95 that lacks the $\mathrm{SH} 3$ domain (PSD-95 $\Delta \mathrm{SH} 3$ ). As seen in Figure 3, overexpression of wild-type PSD-95-GFP significantly decreased dendritic complexity, whereas overexpression of PSD-95 SSH3-GFP had no effect on dendrite number, adding additional support to the importance of the interaction between PSD-95 and EB3 in shaping the dendritic arbor.

\section{Binding of PSD-95 to EB3 decreases EB3 binding to the}

+ TIPs of microtubules and slows microtubule assembly in a cell-free system

We reasoned that by binding to EB3, PSD-95 prevents EB3 from accessing microtubules. Thus, we asked whether the interaction of EB3 and PSD-95 affects the binding of EB3 to the plus ends of microtubules. To address this question, we used COS-7 cells since overexpression of PSD-95 in COS-7 cells results in disorganized microtubules (Charych et al., 2006). Extracts from COS-7 cells transfected with cDNA encoding EB3 fused to GFP, prepared using a microtubule stabilization buffer (Westermann and Weber, 2003), were subjected to immunoprecipitation using an antibody to acetylated tubulin in the presence or absence of purified 
A

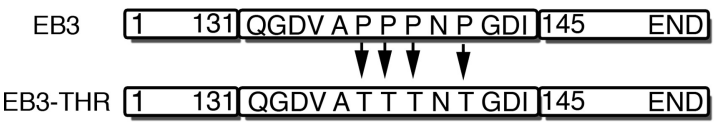

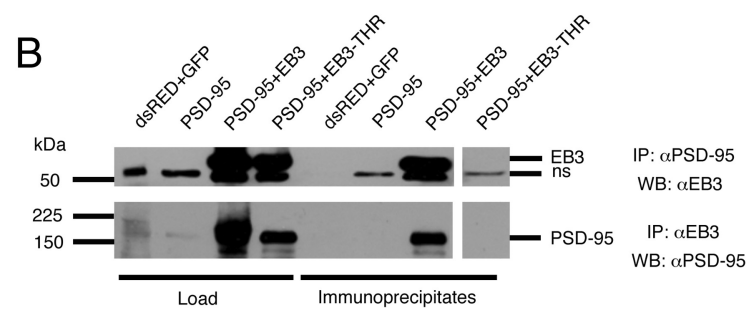

$\mathrm{D}$
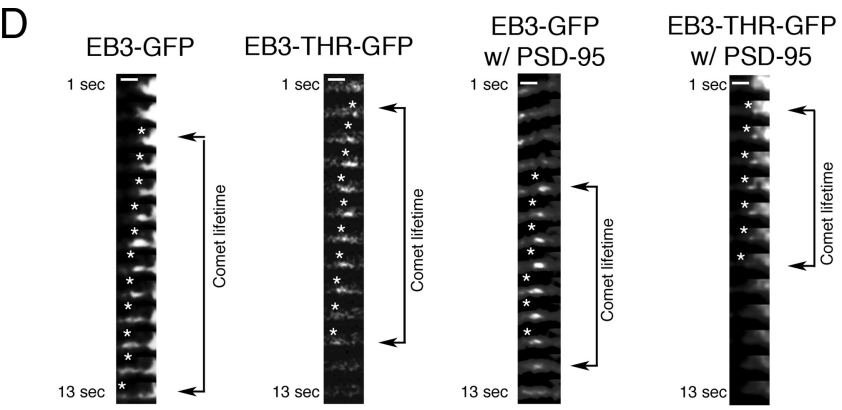

$\mathrm{F}$

$\mathrm{E}$
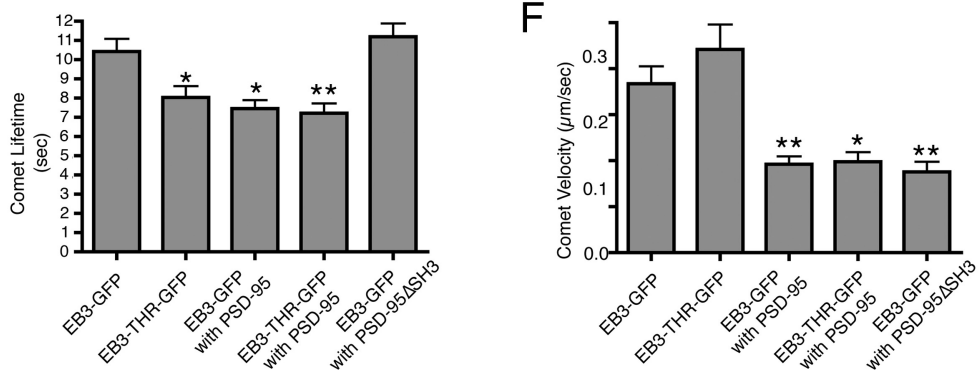

Figure 6. PSD-95 decreases the lifetime of EB3 comets in hippocampal neurons. $A$, Diagram of a mutant form of EB3 with key amino acids of the proline-rich region changed to threonines. $\boldsymbol{B}$, Wild-type, but not EB3-THR, coimmunoprecipitates with PSD-95 from extracts of $\mathrm{COS}-7$ cells coexpressing the indicated proteins. The anti-EB3 antibody used for Western blotting recognizes a nonspecific (ns) $\sim 50 \mathrm{kDa}$ protein band in COS-7 cell lysates. IP, Immunoprecipitation; WB, Western blot. C, Low-magnification images of GFP-tagged EB3 comets in a growing neurite. Asterisks indicate representative comets. $\boldsymbol{D}$, Representative time series images of GFP-tagged EB3 and EB3-THR comets in the dendrites of hippocampal neurons and GFP-tagged EB3 and EB3-THR comets in hippocampal neurons also expressing PSD-95-mRFP or PSD-95 $\triangle$ SH3-mRFP. Images were taken at $18-24 \mathrm{~h}$ posttransfection, which was performed at the time of plating. Scale bars: $1 \mu \mathrm{m}$. Arrows indicate first and last appearances of comets. Asterisks track with tip of the comets. E, Quantitation of the effect of PSD-95-mRFP overexpression on EB3-GFP and EB3-THR-GFP comet lifetime. Overexpression of PSD-95-mRFP decreases the lifetime of EB3-GFP comets but does not decrease the lifetime of EB3-THR-GFP comets. ${ }^{*} p<0.05 ;{ }^{* *} p<0.01$ by Kruskal-Wallis test followed by Dunn's multiple comparison test compared to EB3-GFP. $n \geq 15$ comets for each condition. $\boldsymbol{F}$, Quantitation of the effect of PSD-95 overexpression on EB3-GFP and EB3-THR-GFP comet velocity. Overexpression of PSD-95-GFP decreases the velocity of both EB3-GFP and EB3-THR-GFP comets, suggesting that this effect is not specific to the direct interaction between PSD-95 and EB3. ${ }^{*} p<0.05 ;{ }^{* *} p<0.01$ by Kruskal-Wallis test followed by Dunn's multiple comparison test compared to EB3-GFP. $n \geq 15$ comets for each condition.

GST, GST-PSD-95, or PSD-95 SSH3 (Fig. 4A). As shown in Figure 4, the association of EB3 with immunoprecipitated microtubules was reduced in the presence of GST-PSD-95 but not PSD$95 \Delta \mathrm{SH}$. These results suggest that the binding of EB3 to PSD-95 destabilizes the binding of EB3 to the plus ends of microtubules in these cultures.

How does the binding of PSD-95 to EB3 alter microtubule growth and organization? We used an in vitro cell-free microtubule polymerization assay to assess the kinetics of tubulin polymerization in the presence of purified PSD-95. Surprisingly, these tubulin preparations contain detectable amounts of EB3, as shown by Western blotting with an antibody to EB3 (Fig. 4B).

Our results show that GST-PSD-95, but not GST-PSD-95 $\Delta \mathrm{SH} 3$, decreases the $V_{\text {max }}$ of tubulin polymerization, as determined by light scattering at $\mathrm{OD}_{355}$ (Fig. $4 B, C)$. These results are consistent with the idea that PSD-95 acts to inhibit the binding of EB3 to the plus ends of microtubules, contributing to the destabilization of microtubule polymerization in this assay.

\section{Overexpression of PSD-95 results in altered microtubule organization}

Because EB3 binds to the plus ends of microtubules and rescues them from catastrophe (Komarova et al., 2009) and our results suggest that binding of PSD-95 to EB3 negatively affects EB3 binding to microtubules and subsequent assembly (Fig. 4), we hypothesized that the interaction between PSD-95 and EB3 may cause a change in microtubules in neurons. To assess whether PSD-95 alters microtubule structure in neurons, we performed electron microscopic analysis on transfected cultured neurons. As shown in Figure 5, $A, B$, and $D$, overexpression of PSD-95GFP results in more microtubules that cross at dendrite branch points (Fig. $5 E$, diagram). This change in microtubule architecture was not seen in neurons overexpressing PSD-95 $\Delta$ SH3-GFP (Fig. $5 A, C, D)$. We did not observe a change in the total number of microtubules at branch points when PSD-95 was overexpressed (GFP, $19.17 \pm 0.95$; PSD-95-GFP, $22.00 \pm 2.665 ; n=5$ neurons for each condition; $p>0.05)$. We hypothesized that this change in microtubule structure may be caused, at least in part, by an effect of PSD-95 on EB3 comet dynamics. To assess this, we coexpressed EB3-GFP or EB3-THR-GFP, a mutant in which the prolines have been mutated to threonines, rendering the EB3 unable to bind PSD-95 (Fig. 6A,B) in hippocampal neurons. We measured the movements of these GFPtagged comments in the growing dendrites of young hippocampal neurons (Fig. 6C). We found that the threonine mutation of EB3 lowers the time that EB3 comets spend on the plus tips of the microtubules, referred to as the comet lifetime, but that the mutation does not alter the velocity of the comets (Fig. 6D,F). We also found that coexpression of PSD-95 with EB3-GFP lowered the lifetime of the wild-type comets, but this coexpression did not affect the lifetime of the EB3-THR comets by decreasing it further (Fig. 6D,E). Coexpression of PSD-95 lowered the velocity of both wild-type and mutant comets, suggesting that an interaction of PSD-95 with other + TIP proteins at other domains in PSD-95 may regulate comet velocity (Fig. 6D,F). We also found that when EB3-GFP was coexpressed with PSD-95 $\Delta$ SH3, comet lifetime did not change; 
however, comet velocity was significantly decreased, similar to the effect of coexpressing wild-type PSD-95. Our data strongly suggest that PSD-95 influences microtubule dynamics in neurons via direct interaction of EB3 by specifically affecting how long EB3 comets associate with the microtubule plus end and via interaction with other proteins to affect EB3 comet velocity.

\section{Reduced EB3 comet lifetime correlates with decreased dendritic arborization} To further explore the physiological significance of PSD-95-mediated reduction in EB3 comet lifetime, we examined the effect of overexpression of PSD-95 and EB3 on dendritic arborization. We found that that overexpression of EB3-THRGFP, but not wild-type EB3-GFP, reduced dendritic complexity (Fig. 7 A,B). We also observed that overexpression of PSD-95mRFP reduced dendrite number whether expressed alone or coexpressed with either EB3-GFP or EB3-THR-GFP (Fig. $7 A, C)$. These results are consistent with the effects observed on comet lifetime when these proteins are overexpressed. This indicates that comet lifetime may play a role in the process of dendrite arborization. It is important to note that the effects of PSD-95 on comet velocity may also contribute to decreases seen in dendrite number; however, based on our data, it appears that the direct binding of PSD-95 to EB3 may play a major role in regulating dendritogenesis.

\section{Discussion}

Since dendrite branching involves reorganization of the neuronal cytoskeleton (Jan and Jan, 2003; Parrish et al., 2007), and because the effects of PSD-95 on dendrite branching may involve the alteration of cytoskeletal dynamics (Charych et al., 2006), we hypothesized that PSD-95 achieves these morphological effects through an interaction with microtubule-associated proteins. Our results show that PSD-95 directly interacts with the microtubule plus-end binding protein EB3, a member of the + TIP family of microtubuleassociated proteins, by a direct interaction of the PSD-95 SH3 domain with a proline-rich region within the EB3 polypeptide. When the interaction between PSD-95 and EB3 was disturbed using functional mutational analysis, we observed an elimination of the effect of PSD-95 on dendrite number and branching and EB3 comet behavior. It is important to note that although the $\mathrm{SH} 3$ domain of PSD-95 interacts with the GK domain and is required for establishing a stable lattice in the postsynaptic density, it is not required for localization to the synapse (Craven et al., 1999; McGee and Bredt, 1999; Shin et al., 2000; Sturgill et al., 2009). Thus, the lack of effect of the PSD-95 $\Delta$ SH3 mutant, which cannot bind to EB3, on dendrite number and comet velocity is not attributable to improper localization.
We now show for the first time that PSD-95 alters EB3 comet dynamics, and hence microtubule dynamics, in developing neurons. Overexpression of PSD-95 resulted in a reduced lifetime of only wild-type, but not mutant, EB3 comets. The reduction of the time that EB3 spends at the tip of the microtubule in the presence of excess PSD-95 may be attributable to displacement of EB3 from microtubules, as evidenced by our cell-free studies, or it may be because of a reduction of the available pool for the rapidly cycling EB3 molecule (Dragestein et al., 2008). Our observed effect of PSD-95 overexpression on comet lifetime matches the results from our studies on the effects of PSD-95 and EB3 on dendritic arborization. Overexpression of EB3-THR alone or PSD-95 in the presence of EB3 or EB3-THR results in decreased dendritic complexity. These data suggest that decreased EB3 comet lifetime may play a role in regulating dendritic arborization. This role of comet lifetime is also supported by the fact that expression of a mutant PSD-95 containing a deletion of the $\mathrm{SH} 3$ domain from PSD-95 results in no effect on dendrite branching 

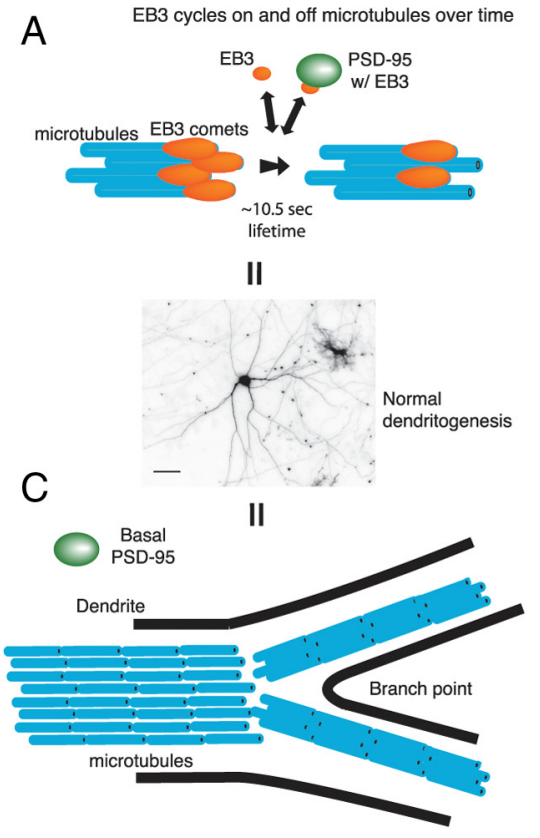

Microtubules are highly organized at branch points
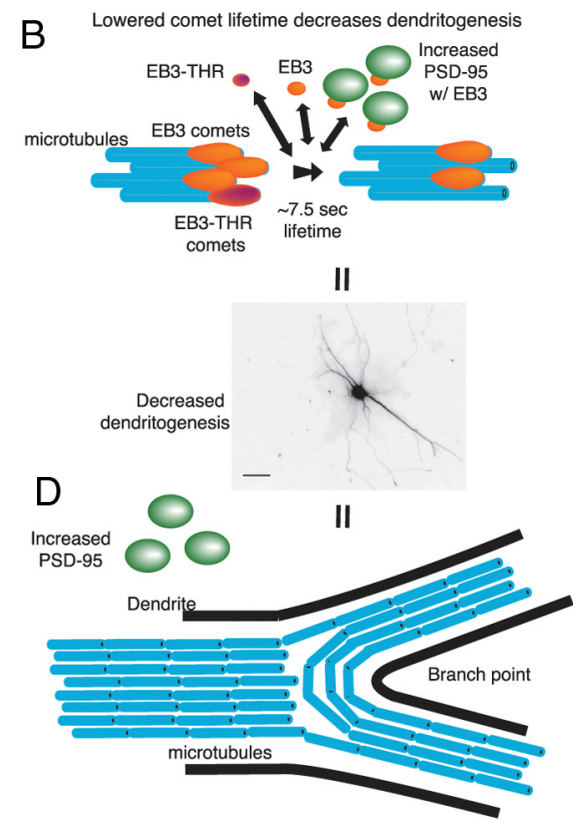

Disruption of the organization decreases dendritogenesis

Figure 8. Model of the roles of PSD-95 and EB3 in regulating dendritogenesis. $A$, Under control conditions, $\mathrm{EB} 3$ comets have a lifetime of $\sim 10.5 \mathrm{~s}$. This time is influenced by the cycling of $\mathrm{EB} 3$ on and off of the plus end of the microtubule and the cycles of microtubule catastrophe and rescue. Endogenous PSD-95 interacts with EB3. $\boldsymbol{B}$, When PSD-95 or EB3-THR is overexpressed, EB3 comet lifetime decreases, leading to reduced dendritic complexity. EB3-THR comets remain on microtubules for a shorter amount of time than do wild-type comets, and increased PSD-95 expression may sequester EB3, reducing its lifetime at the plus end of microtubules. $\boldsymbol{C}$, In control neurons, microtubules do not cross at branch points frequently. $\boldsymbol{D}$, When PSD-95 is overexpressed, the frequency of microtubules that cross between dendritic branches increases. Scale bars in example images of neurons: $50 \mu \mathrm{m}$. agree on is that disrupting comet appearance on the $+T I P$ alters microtubule dynamics. Our data indicate that the effects of PSD-95 on EB3 comet lifetime include changes in microtubule dynamics and that these changes correlate to altered microtubule organization that may influence dendrite morphology. We confirmed these effects of PSD-95 using electron microscopy and observed that microtubules of neurons that overexpress PSD-95 cross more at branch points than do microtubules of neurons expressing GFP or PSD-95 $\Delta$ SH3. This organizational change could influence dendrite morphology by inhibiting the formation of new branches or stabilizing existing ones. The microtubules that cross at the branches may be oriented with their plus ends toward the nucleus, which would have implications in transport of dendritic cargo (Burack et al., 2000). One confounding factor may be the role of the actin cytoskeleton. It has been shown that EB3 acts to bring actin remodeling molecules to the cell membrane, and disrupting this interaction may prevent microtubules from interacting with F-actin, which is important for neurite extension (Dent et al., 2007; Geraldo et al., 2008).

Our present study sheds light on the or comet lifetime but does decrease comet velocity. Our new data, summarized by the model shown in Figure 8, provide a potential mechanism for the function by which PSD-95 acts during the course of neuronal development.

It is also of interest that the velocity of both wild-type and mutant EB3 comets were both reduced by PSD-95. This result suggests that PSD-95 may be acting in an indirect manner to control this characteristic of EB3 comets and that other molecules may play a role in this interaction. The regulation of the dynamic nature of the plus ends of microtubules is very complex and involves many protein interactions (Nakamura et al., 2001; Jimbo et al., 2002; Wen et al., 2004). For example, the PDZ domains of PSD-95 can bind to APC (Yanai et al., 2000), and EB3 interacts with APC to regulate microtubule dynamics and targeting (Nakagawa et al., 2000). CLIP-170, another + TIP protein, can bind to microtubules and EB1 through separate domains (Gupta et al., 2009), providing a potential model for interaction at the plus end of the microtubule (Fukata et al., 2002a; Ligon et al., 2006; Lewkowicz et al., 2008). Although APC and CLIP-170 represent two possible interactors for PSD-95 action at the plus end, an indirect interaction of another + TIP protein binding to a different domain of PSD-95 may act to regulate EB3 comet velocity, whereas the direct interaction between PSD-95 and EB3 regulates comet lifetime.

What is the physiological significance of the regulation of EB3 comet lifetime by PSD-95? There has been some debate in the field about the affect of EB proteins on microtubule dynamics. Studies done in a number of cell lines and conditions have attributed a very complex, sometimes conflicting, set of behaviors to the EB proteins (Vitre et al., 2008; Komarova et al., 2009; van der Vaart et al., 2009; Stepanova et al., 2010). What all of the studies newly discovered interaction between EB3 and PSD-95 at the + TIP. We reported previously that PSD-95 alters dendrite branching in cultured hippocampal neurons and that this effect might result from the alteration of microtubule dynamics (Charych et al., 2006). We have now shown that the direct interaction of PSD-95, an integral part of the post-synaptic apparatus, and EB3, an essential regulator of microtubule dynamics, correlates to changes in the microtubule network, which shapes dendritic structure. The study of this interaction provides additional insight into the complex organization of molecules at the plus end of microtubules and into the mechanism of dendritogenesis.

\section{References}

Akhmanova A, Hoogenraad CC (2005) Microtubule plus-end-tracking proteins: mechanisms and functions. Curr Opin Cell Biol 17:47-54.

Akhmanova A, Steinmetz MO (2008) Tracking the ends: a dynamic protein network controls the fate of microtubule tips. Nat Rev Mol Cell Biol 9:309-322.

Akum BF, Chen M, Gunderson SI, Riefler GM, Scerri-Hansen MM, Firestein BL (2004) Cypin regulates dendrite patterning in hippocampal neurons by promoting microtubule assembly. Nat Neurosci 7:145-152.

Berman H, Henrick K, Nakamura H, Markley JL (2007) The worldwide Protein Data Bank (wwPDB): ensuring a single, uniform archive of PDB data. Nucleic Acids Res 35:D301-D303.

Brenman JE, Christopherson KS, Craven SE, McGee AW, Bredt DS (1996) Cloning and characterization of postsynaptic density 93, a nitric oxide synthase interacting protein. J Neurosci 16:7407-7415.

Brenman JE, Topinka JR, Cooper EC, McGee AW, Rosen J, Milroy T, Ralston HJ, Bredt DS (1998) Localization of postsynaptic density-93 to dendritic microtubules and interaction with microtubule-associated protein $1 \mathrm{~A}$. J Neurosci 18:8805-8813.

Burack MA, Silverman MA, Banker GA (2000) The role of selective transport in neuronal protein sorting. Neuron 26:465-472.

Charych EI, Akum BF, Goldberg JS, Jörnsten RJ, Rongo C, Zheng JQ, Firest- 
ein BL (2006) Activity-independent regulation of dendrite patterning by postsynaptic density protein PSD-95. J Neurosci 26:10164-10176.

Chen H, Firestein BL (2007) RhoA regulates dendrite branching in hippocampal neurons by decreasing cypin protein levels. J Neurosci 27:8378-8386.

Chen L, Chetkovich DM, Petralia RS, Sweeney NT, Kawasaki Y, Wenthold RJ, Bredt DS, Nicoll RA (2000) Stargazin regulates synaptic targeting of AMPA receptors by two distinct mechanisms. Nature 408:936-943.

Chen M, Lucas KG, Akum BF, Balasingam G, Stawicki TM, Provost JM, Riefler GM, Jörnsten RJ, Firestein BL (2005) A novel role for snapin in dendrite patterning: interaction with cypin. Mol Biol Cell 16:5103-5114.

Cho KO, Hunt CA, Kennedy MB (1992) The rat brain postsynaptic density fraction contains a homolog of the Drosophila discs-large tumor suppressor protein. Neuron 9:929-942.

Chung HJ, Huang YH, Lau LF, Huganir RL (2004) Regulation of the NMDA receptor complex and trafficking by activity-dependent phosphorylation of the NR2B subunit PDZ ligand. J Neurosci 24:10248-10259.

Clark M, Cramer III RD, Van Opdenbosch N (1989) Validation of the general purpose Tripos 5.2 force field. J Comput Chem 10:982-1012.

Craven SE, El-Husseini AE, Bredt DS (1999) Synaptic targeting of the postsynaptic density protein PSD-95 mediated by lipid and protein motifs. Neuron 22:497-509.

De Groot CO, Jelesarov I, Damberger FF, Bjelic S, Schaerer MA, Bhavesh NS, Grigoriev I, Buey RM, Wuthrich K, Capitani G, Akhmanova A, Steinmetz MO (2009) Molecular insights into mammalian end binding protein heterodimerization. J Biol Chem 285:5802-5814.

Dent EW, Kwiatkowski AV, Mebane LM, Philippar U, Barzik M, Rubinson DA, Gupton S, Van Veen JE, Furman C, Zhang J, Alberts AS, Mori S, Gertler FB (2007) Filopodia are required for cortical neurite initiation. Nat Cell Biol 9:1347.

Dotti CG, Sullivan CA, Banker GA (1988) The establishment of polarity by hippocampal neurons in culture. J Neurosci 8:1454-1468.

Dragestein KA, van Cappellen WA, van Haren J, Tsibidis GD, Akhmanova A, Knoch TA, Grosveld F, Galjart N (2008) Dynamic behavior of GFPCLIP-170 reveals fast protein turnover on microtubule plus ends. J Cell Biol 180:729-737.

El-Husseini AE, Schnell E, Chetkovich DM, Nicoll RA, Bredt DS (2000) PSD-95 involvement in maturation of excitatory synapses. Science 290:1364-1368.

Fernando LP, Khan ZU, De Blas AL (1995) Antibodies to the rat beta 3 subunit of the gamma-aminobutyric acid A receptors. Brain Res Mol Brain Res 28:94-100.

Firestein BL, Brenman JE, Aoki C, Sanchez-Perez AM, El-Husseini AE, Bredt DS (1999) Cypin: a cytosolic regulator of PSD-95 postsynaptic targeting. Neuron 24:659-672.

Fukata M, Watanabe T, Noritake J, Nakagawa M, Yamaga M, Kuroda S, Matsuura Y, Iwamatsu A, Perez F, Kaibuchi K (2002a) Rac1 and Cdc42 capture microtubules through IQGAP1 and CLIP-170. Cell 109:873-885.

Fukata Y, Itoh TJ, Kimura T, Ménager C, Nishimura T, Shiromizu T, Watanabe H, Inagaki N, Iwamatsu A, Hotani H, Kaibuchi K (2002b) CRMP-2 binds to tubulin heterodimers to promote microtubule assembly. Nat Cell Biol 4:583-591.

Gasteiger J, Marsili M (1980) Iterative partial equalization of orbital electronegativity—a rapid access to atomic charges. Tetrahedron 32:3219-3228.

Geraldo S, Khanzada UK, Parsons M, Chilton JK, Gordon-Weeks PR (2008) Targeting of the F-actin-binding protein drebrin by the microtubule plus-tip protein EB3 is required for neuritogenesis. Nat Cell Biol 10:1181-1189.

Gupta KK, Joyce MV, Slabbekoorn AR, Zhu Z, Paulson BA, Boggess B, Goodson HV (2009) Probing interactions between CLIP-170, EB1, and microtubules. J Mol Biol 395:1049-1062.

Honnappa S, Gouveia SM, Weisbrich A, Damberger FF, Bhavesh NS, Jawhari H, Grigoriev I, van Rijssel FJA, Buey RM, Lawera A, Jelesarov I, Winkler FK, Wüthrich K, Akhmanova A, Steinmetz MO (2009) An EB1-binding motif acts as a microtubule tip localization signal. Cell 138:366-376.

Jan YN, Jan LY (2003) The control of dendrite development. Neuron 40:229-242.

Jaworski J, Kapitein LC, Gouveia SM, Dortland BR, Wulf PS, Grigoriev I, Camera P, Spangler SA, Di Stefano P, Demmers J, Krugers H, Defilippi P, Akhmanova A, Hoogenraad CC (2009) Dynamic microtubules regulate dendritic spine morphology and synaptic plasticity. Neuron 61:85-100.

Jimbo T, Kawasaki Y, Koyama R, Sato R, Takada S, Haraguchi K, Akiyama T
(2002) Identification of a link between the tumour suppressor APC and the kinesin superfamily. Nat Cell Biol 4:323-327.

Jones G, Willett P, Glen RC, Leach AR, Taylor R (1997) Development and validation of a genetic algorithm for flexible docking. J Mol Biol 267:727-748.

Kim JH, Liao D, Lau LF, Huganir RL (1998) SynGAP: a synaptic RasGAP that associates with the PSD-95/SAP90 protein family. Neuron 20:683-691.

Kistner U, Wenzel BM, Veh RW, Cases-Langhoff C, Garner AM, Appeltauer U, Voss B, Gundelfinger ED, Garner CC (1993) SAP90, a rat presynaptic protein related to the product of the Drosophila tumor suppressor gene dlg-A. J Biol Chem 268:4580-4583.

Komarova Y, Lansbergen G, Galjart N, Grosveld F, Borisy GG, Akhmanova A (2005) EB1 and EB3 control CLIP dissociation from the ends of growing microtubules. Mol Biol Cell 16:5334-5345.

Komarova Y, De Groot CO, Grigoriev I, Gouveia SM, Munteanu EL, Schober JM, Honnappa S, Buey RM, Hoogenraad CC, Dogterom M, Borisy GG, Steinmetz MO, Akhmanova A (2009) Mammalian end binding proteins control persistent microtubule growth. J Cell Biol 184:691-706.

Lansbergen G, Akhmanova A (2006) Microtubule plus end: a hub of cellular activities. Traffic 7:499-507.

Lewkowicz E, Herit F, Le Clainche C, Bourdoncle P, Perez F, Niedergang F (2008) The microtubule-binding protein CLIP-170 coordinates mDial and actin reorganization during CR3-mediated phagocytosis. J Cell Biol 183:1287-1298.

Ligon LA, Shelly SS, Tokito MK, Holzbaur EL (2006) Microtubule binding proteins CLIP-170, EB1, and p150Glued form distinct plus-end complexes. FEBS Lett 580:1327-1332.

Manna T, Grenningloh G, Miller HP, Wilson L (2007) Stathmin family protein SCG10 differentially regulates the plus and minus end dynamics of microtubules at steady state in vitro: implications for its role in neurite outgrowth. Biochemistry 46:3543-3552.

Masahira N, Ding L, Takebayashi H, Shimizu K, Ikenaka K, Ono K (2005) Improved preservation of X-gal reaction product for electron microscopy using hydroxypropyl methacrylate. Neurosci Lett 374:17-20.

McGee AW, Bredt DS (1999) Identification of an intramolecular interaction between the SH3 and guanylate kinase domains of PSD-95. J Biol Chem 274:17431-17436.

McGee AW, Dakoji SR, Olsen O, Bredt DS, Lim WA, Prehoda KE (2001) Structure of the SH3-guanylate kinase module from PSD-95 suggests a mechanism for regulated assembly of MAGUK scaffolding proteins. Mol Cell 8:1291-1301.

Myers KA, Baas PW (2007) Kinesin-5 regulates the growth of the axon by acting as a brake on its microtubule array. J Cell Biol 178:1081-1091.

Nakagawa H, Koyama K, Murata Y, Morito M, Akiyama T, Nakamura Y (2000) EB3, a novel member of the EB1 family preferentially expressed in the central nervous system, binds to a CNS-specific APC homologue. Oncogene 19:210-216.

Nakamura M, Zhou XZ, Lu KP (2001) Critical role for the EB1 and APC interaction in the regulation of microtubule polymerization. Curr Biol 11:1062-1067.

Parrish JZ, Emoto K, Kim MD, Jan YN (2007) Mechanisms that regulate establishment, maintenance, and remodeling of dendritic fields. Annu Rev Neurosci 30:399-423.

Passafaro M, Sala C, Niethammer M, Sheng M (1999) Microtubule binding by CRIPT and its potential role in the synaptic clustering of PSD-95. Nat Neurosci 2:1063-1069.

Pettersen EF, Goddard TD, Huang CC, Couch GS (2004) UCSF Chimera-a visualization system for exploratory research and analysis. J Comput Chem 25:1605-1612.

Qiang L, Yu W, Andreadis A, Luo M, Baas PW (2006) Tau protects microtubules in the axon from severing by katanin. J Neurosci 26:3120-3129.

Reese ML, Dakoji S, Bredt DS, Dötsch V (2007) The guanylate kinase domain of the MAGUK PSD-95 binds dynamically to a conserved motif in MAP1a. Nat Struct Mol Biol 14:155-163.

Sans N, Petralia RS, Wang YX, Blahos J, Hell JW, Wenthold RJ (2000) A developmental change in NMDA receptor-associated proteins at hippocampal synapses. J Neurosci 20:1260-1271.

Shin H, Hsueh YP, Yang FC, Kim E, Sheng M (2000) An intramolecular interaction between Src homology 3 domain and guanylate kinase-like domain required for channel clustering by postsynaptic density-95/ SAP90. J Neurosci 20:3580-3587. 
Steiner P, Higley MJ, Xu W, Czervionke BL, Malenka RC, Sabatini BL (2008) Destabilization of the postsynaptic density by PSD-95 serine 73 phosphorylation inhibits spine growth and synaptic plasticity. Neuron 60:788-802.

Stepanova T, Slemmer J, Hoogenraad CC, Lansbergen G, Dortland B, De Zeeuw CI, Grosveld F, van Cappellen G, Akhmanova A, Galjart N (2003) Visualization of microtubule growth in cultured neurons via the use of EB3-GFP (end-binding protein 3-green fluorescent protein). J Neurosci 23:2655-2664.

Stepanova T, Smal I, van Haren J, Akinci U, Liu Z, Miedema M, Limpens R, van Ham M, van der Reijden M, Poot R, Grosveld F, Mommaas M, Meijering E, Galjart N (2010) History-dependent catastrophes regulate axonal microtubule behavior. Curr Biol 20:1023-1028.

Sturgill JF, Steiner P, Czervionke BL, Sabatini BL (2009) Distinct domains within PSD-95 mediate synaptic incorporation, stabilization, and activity-dependent trafficking. J Neurosci 29:12845-12854.

Tavares GA, Panepucci EH, Brunger AT (2001) Structural characterization of the intramolecular interaction between the $\mathrm{SH} 3$ and guanylate kinase domains of PSD-95. Mol Cell 8:1313-1325.

van der Vaart B, Akhmanova A, Straube A (2009) Regulation of microtubule dynamic instability. Biochem Soc Trans 37:1007-1013.
Vitre B, Coquelle F, Heichette C, Garnier C, Chrétien D, Arnal I (2008) EB1 regulates microtubule dynamics and tubulin sheet closure in vitro. Nat Cell Biol 10:415-421.

Wen Y, Eng CH, Schmoranzer J, Cabrera-Poch N, Morris EJ, Chen M, Wallar BJ, Alberts AS, Gundersen GG (2004) EB1 and APC bind to mDia to stabilize microtubules downstream of Rho and promote cell migration. Nat Cell Biol 6:820-830.

Wersinger C, Sidhu H (2005) Disruption of the interaction of alpha-synuclein with microtubules enhances cell surface recruitment of the dopamine transporter. Biochemistry 44:13612-13624.

Westermann S, Weber K (2003) Post-translational modifications regulate microtubule function. Nat Rev Mol Cell Biol 4:938-947.

Xia Z, Dudek H, Miranti CK, Greenberg ME (1996) Calcium influx via the NMDA receptor induces immediate early gene transcription by a MAP kinase/ERK-dependent mechanism. J Neurosci 16:5425-5436.

Yanai H, Satoh K, Matsumine A, Akiyama T (2000) The colorectal tumour suppressor APC is present in the NMDA-receptor-PSD-95 complex in the brain. Genes Cells 5:815-822.

Yu X, Malenka RC (2004) Multiple functions for the cadherin/catenin complex during neuronal development. Neuropharmacology 47:779-786. 